\title{
Variation in Dental Crown Morphology in Malaysian Populations
}

\author{
Mohd Fadhli Khamis ${ }^{1 *}$, Jane A. Taylor ${ }^{2}$, Abdul Rani Samsudin ${ }^{1}$, and Grant C. Townsend ${ }^{3}$ \\ ${ }^{1}$ School of Dental Sciences, Universiti Sains Malaysia, Kota Bharu, Kelantan 16150 Malaysia \\ ${ }^{2}$ Oral Health, The University of Newcastle, Ourimbah, New South Wales, Australia \\ ${ }^{3}$ School of Dentistry, The University of Adelaide, Adelaide SA 5005, Australia
}

\begin{abstract}
Dental crown variation was studied in the four main population groups living in Malaysia using dental casts (upper and lower) obtained from 790 individuals. The aims of the study were to characterize variation in 13 dental crown traits, within groups as well as between groups, and to assess affinities between the groups based on frequencies of occurrence of dental features. Using chi-square analysis and Fisher's exact test, the majority of dental traits were found to be bilaterally symmetrical and to demonstrate low sexual dimorphism. Comparisons of trait frequencies between
\end{abstract}

Interms of historicalmigrations and interrelationships of people, Malaysia has been compared to the United States of America (Nagata, 1979) in being a home to many different people from different ethnic backgrounds. Until now, descriptions of contemporary Malaysian dental crown morphology have been lacking, with only two published reports available, as far as we aware.

Tratman (1950) described dental variations between Mongoloids and Indians from the Malaysian Peninsula andSingapore. Hecombined Malays and Chineseinto one regional group for his comparisons, while Indians were categorized as representing Indo-Europeans; however, his report was limited to anatomical descriptions without statistical analyses (except for a few traits) due to loss of data during World War II. Another report on the dentition of Malaysians by Rusmah (1992) presented frequencies of occurrence for Carabelli cusp, which was present in $52.2 \%$ of the sample. Rusmah reported that no sexual dimorphism or bilateral asymmetry was evident for this trait.

Previous studies of dental affinities among Asians have revealed that Mongoloid people can be subdivided into Sinodonts, represented by Northern Asians and Native Americans, and Sundadonts comprising peoples of South-East Asia (Turner, 1987; 1990). From 28 traits used initially to separate East Asians into Northern and Southern divisions, Turner (1990) found eight traits that discriminated between Sinodonts and Sundadonts. All of these traits occurred more frequently in Sinodonts, groups revealed similarities between Malays, Jahai (Negritos) and Chinese who conformed to Mongoloid Sinodont-Sundadont dental patterns, whereas the Indians conformed to an Indo-European pattern. Phenetic distance analysis, using the mean measure of divergence, showed that Indians were markedly separated from the other three groups, while Malays were closer to Jahai than to Chinese. These findings based on dental traits are consistent with historical explanations of affinities between modern Malaysian populations. Dental Anthropology 2006;19(2):49-60.

except for 4-cusped lower second molars. Turner described Sinodonts as having trait intensification, that is, higher frequencies of crown trait occurrence and addition (e.g., three rooted lower first molars), while Sundadonts showed crown simplification or moderate frequencies of occurrence, and retention of old traits (e.g., two-rooted upper first premolars).

Traditionally, relationships among Malaysian populations have been based only on historical perspectives. Malays and Orang Asli are considered to be the natives of Malaysia, while Chinese and Indians arrived for trade and economic opportunities mainly during the British colonization period in the early 19th century (Nagata, 1979; Pusat Perkembangan Kurikulum, 1998; Zainuddin, 2003). Many questions still remain about the origins of Malaysians and their affinities from a biological point of view.

It is important to describe the nature and extent of dental variation within populations before attempting to characterize variation between them. This includes

Grant sponsorship: Universiti Sains Malaysia short term grant 304/PPSG/6131274 and South Australian Police.

*Correspondence to: Mohd Fadhli Khamis, School of Dental Sciences, Health Campus, Universiti Sains Malaysia, Kota Bharu 16150 Kelantan, Malaysia.

E-mail: fadhli@kb.usm.my 
consideration of the nature and extent of sexual dimorphism, bilateral asymmetry and inter-trait associations. Scott and Turner (1997) have concluded that dental morphological traits are suitable for population characterization due to their low sexual dimorphism and strong symmetry, and several researchers have found no evidence of significant sexual dimorphism for various dental traits (Garn et al., 1966b; Bang and Hasund, 1971; Bang and Hasund, 1972; Hanihara, 1977; Turner and Hanihara, 1977; Turner and Scott, 1977; Hershey, 1979; Scott, 1980; Hassanali, 1982; Mayhall et al., 1982; Kieser, 1984; Thomas et al., 1986; Townsend et al., 1986; Haeussler et al., 1989; Townsend et al., 1990; Manabe et al., 1992; Rusmah, 1992; Kannappan and Swaminathan, 1998). Other researchers, however, have noted higher frequencies for certain features in males (Rothhammer et al., 1968; Escobar et al., 1977; Scott, 1977; Townsend and Brown, 1981; Iwai-Liao et al., 1996; Hsu et al., 1997) and occasionally in females (Harris and Bailit, 1980). Several studies have indicated that dental traits tend to be expressed symmetrically (Baume and Crawford, 1979; Harris and Bailit, 1980; Noss et al., 1983b; Townsend et al., 1990) while others have reported evidence of asymmetry (Meredith and Hixon, 1954; Mayhall and Saunders, 1986; Moskona et al., 1996).

Given the limited information available about Malaysian odontological variation, this study aimed to characterize variation of dental crown traits within four major Malaysian ethnic groups prior to undertaking a study of the affinities between them.

\section{MATERIALS AND METHODS}

A total of 790 sets of dental casts (maxillary and mandibular) were examined in this study. Table 1 shows the sample distribution according to sex and age for each of the four ethnic groups. All groups comprised teenagers from the districts around Kelantan and Perak, except for the Jahai (Negritos) who were older. The Jahai represent a sub-group of Negritos who live mainly in the northern part of the Malaysian Peninsula. The Negritos are one of three Orang Asli tribes who live only on the Malaysian Peninsula. Power studies following the methods of Dupont and Plummer (1997) indicated that sample sizes of 72 for each group would be sufficient to provide $80 \%$ power for our study. Logistic, financial and time constraints restricted the number of Jahai who could be recruited into the study and, consequently, results for this group should be interpreted with caution.

The classification of dental crown traits, except those for the entoconulid, Carabelli trait and groove pattern, was simplified from the Arizona State University (ASU) classification system (Turner et al., 1991). Teeth were not scored if wear obscured the trait under investigation. The ASU reference plaques were used when scoring all traits to provide additional guidance. The definition of Townsend et al. (1990) was used for entoconulid classification as it includes observation of the entoconulid on four-cusped molars, whereas the ASU system only scores entoconulids on five-cusped molars. Carabelli trait was scored according to Dahlberg's plaque P12A, and molar groove pattern was assessed using plaque P10 (Dahlberg, 1956). For the other traits, the original ASU gradings were simplified into two or three grades of expression only (Table 2). Table 2 also provides the breakpoints chosen for the dichotomous data.

Dental casts for 167 individuals were scored twice and intra-observer errors for graded scales and presence/ absence for all traits were calculated as percentages of discordance following Nichol and Turner (1986). These authors set $10 \%$ discordance as a benchmark for 2-grade discrepancies and presence-absence data.

The extent of asymmetrical expression of the dental traits in males was compared initially with that in females using chi-square analysis or Fisher's exact test when expected cell frequencies were less than five (Howitt and Cramer, 2003). Absent-absent pairs were excluded from the analysis. These preliminary tests were used to determine whether it would be appropriate to pool data for subsequent analyses of symmetry/asymmetry. An adjusted alpha level was set at $0.05 / 12=0.004$ (Bonferroni's adjustment).

Comparisons of the frequencies of occurrence of dental traits on corresponding right and left teeth were tested using non-parametric analyses, either Fisher's exact test, or Monte Carlo Estimates (SPSS Inc., 19892001, version 11.0.1).

Frequencies of occurrence and degrees of expression were calculated for all traits. Sexual dimorphism was

TABLE 1. Distribution of participants according to sex and age within four ethnic groups ${ }^{1}$

\begin{tabular}{llrlr}
\hline $\begin{array}{c}\text { Ethnic } \\
\text { group }\end{array}$ & Sex & \multicolumn{1}{c}{$\mathrm{n}$} & $\begin{array}{c}\text { Mean } \\
\text { (years) }\end{array}$ & sd \\
\hline Malays & Female & 167 & 15.6 & 1.2 \\
& Male & 126 & 15.1 & 1.3 \\
& Total & 293 & 15.4 & 1.3 \\
Chinese & Female & 88 & 14.5 & 1.3 \\
& Male & 90 & 14.7 & 1.5 \\
& Total & 178 & 14.6 & 1.4 \\
Indians & Female & 131 & 15.8 & 1.4 \\
& Male & 121 & 15.6 & 1.3 \\
& Total & 252 & 15.7 & 1.3 \\
Negritos & Female & 33 & 28.3 & 8.2 \\
(Jahai) & Male & 34 & 30.5 & 13.1 \\
& Total & 67 & 29.4 & 10.9 \\
Total & Female & 419 & 16.4 & 4.4 \\
& Male & 371 & 16.6 & 6.1 \\
& Total & 790 & 16.5 & 5.2 \\
\hline
\end{tabular}

${ }^{1} \mathrm{n}$ is sample size; sd is standard deviation 
TABLE 2. Dental crown trait classification used in this study

\begin{tabular}{|c|c|c|c|c|c|}
\hline Trait & Tooth & Classification & $\begin{array}{l}\text { ASU } \\
\text { grade }\end{array}$ & Score $^{1}$ & $\begin{array}{c}\text { Breakpoint for } \\
\text { dichotomous data }^{2}\end{array}$ \\
\hline \multirow[t]{3}{*}{ Winging } & \multirow[t]{3}{*}{11,21} & Bilateral winging & 1 & 1 & 1-present \\
\hline & & Unilateral winging & 2 & 2 & 2,3-absent \\
\hline & & Counter wing and straight & $\mathrm{t} \quad 3,4$ & 3 & \\
\hline \multirow[t]{4}{*}{ Shovel } & \multirow[t]{4}{*}{11,21} & Absent & & 0 & 0 0,1-absent \\
\hline & & Trace & 1,2 & 1 & 2,3-present \\
\hline & & Semi & 3,4 & 2 & \\
\hline & & Shovel & 5,6 & 3 & \\
\hline \multirow[t]{4}{*}{ Metaconule } & \multirow[t]{4}{*}{16,26} & Absent & 0 & 0 & 0 -absent \\
\hline & & Weak cuspule & 1,2 & 1 & 1,2,3-present \\
\hline & & Small cuspule & 3 & 2 & \\
\hline & & Small to moderate cusp & 4,5 & 3 & \\
\hline \multirow[t]{4}{*}{ Carabelli trait ${ }^{3}$} & \multirow[t]{4}{*}{16,26} & Absent & a & 0 & 0 -absent \\
\hline & & Pit \& furrow & $b, c$ & 1 & 123-present \\
\hline & & Tubercle & $d, e, f, g$ & 2 & \\
\hline & & Cusp & $\mathrm{h}$ & 3 & \\
\hline \multirow[t]{4}{*}{ Hypocone } & \multirow[t]{4}{*}{17,27} & Absent or ridge & 0,1 & 0 & 0,1-absent \\
\hline & & Cuspule & 2 & 1 & 2,3-present \\
\hline & & Reduced cusp & 3,4 & 2 & \\
\hline & & Large & 5,6 & 3 & \\
\hline \multirow[t]{3}{*}{ Distal accessory ridge } & \multirow[t]{3}{*}{33,43} & Absent & 0 & 0 & 0 -absent \\
\hline & & Weak & 1,2 & 1 & 1,2-present \\
\hline & & Strong & $3,4,5$ & 2 & \\
\hline \multirow[t]{4}{*}{ Lingual cusp number } & \multirow[t]{4}{*}{35,45} & One & & 1 & 1-one cusp \\
\hline & & Two & & 2 & \\
\hline & & Three & & 3 & 2,3,4-not one cusp \\
\hline & & Four & & 4 & \\
\hline \multirow[t]{3}{*}{ Protostylid } & \multirow[t]{3}{*}{36,46} & Absent & 0 & 0 & 0 -absent \\
\hline & & Weak & $1,2,3$ & 1 & 1,2-present \\
\hline & & Strong & $4,5,6,7$ & 2 & \\
\hline \multirow[t]{3}{*}{ Metaconulid } & \multirow[t]{3}{*}{36,46} & Absent & $0,1,5$ & 0 & 0 -absent \\
\hline & & Small & $1,2,3$ & 1 & 1,2-present \\
\hline & & Large & 4 & 2 & \\
\hline \multirow[t]{3}{*}{ Entoconulid } & \multirow[t]{3}{*}{36,46} & Absent & 0 & 0 & 0 -absent \\
\hline & & Weak & 1,2 & 1 & 1,2-present \\
\hline & & Strong & 3,4 & 2 & \\
\hline \multirow[t]{3}{*}{ Deflecting wrinkle } & \multirow[t]{3}{*}{36,46} & Absent & 0,1 & 0 & 0,1-absent \\
\hline & & Weak & 2 & 1 & 2-present \\
\hline & & Strong & 3 & 2 & \\
\hline \multirow[t]{3}{*}{ Cusp number } & \multirow[t]{3}{*}{37,47} & Four & & 4 & 4-four cusp \\
\hline & & Five & & 5 & 5,6-not four cusp \\
\hline & & Six & & 6 & \\
\hline Groove pattern ${ }^{4}$ & 37,47 & $\mathrm{Y}$ & Y & 1 & 1-Y pattern \\
\hline & & + & + & 2 & $2,3-+, X$ pattern \\
\hline & & $X$ & $X$ & 3 & \\
\hline
\end{tabular}

${ }^{1}$ score used in this study

${ }^{2}$ breakpoint based on ${ }^{1}$

${ }^{3}$ observation using Dahlberg plaque P12A

${ }^{4}$ observation using Dahlberg plaque P10. 
TABLE 3. Tests of bilateral symmetry for 12 dental crown traits using graded-scale data (pooled-sex data) ${ }^{1}$

\begin{tabular}{|c|c|c|c|c|c|}
\hline Traits and Teeth & & Malays & Chinese & Indians & $\begin{array}{r}\text { Negritos } \\
\text { (Jahai) }\end{array}$ \\
\hline Shovel 11,21 & $\begin{array}{l}\mathrm{n} \\
\% \text { symmetry } \\
\% \text { symmetry (absent-absent exc.) } \\
\text { rho }\end{array}$ & $\begin{array}{l}266 \\
95.1^{\mathrm{a}} \\
95.0 \\
0.91^{\mathrm{b}}\end{array}$ & $\begin{array}{l}170 \\
90.6^{\mathrm{a}} \\
90.6 \\
0.80^{\mathrm{b}}\end{array}$ & $\begin{array}{l}218 \\
96.8^{\mathrm{a}} \\
96.7 \\
0.93^{\mathrm{b}}\end{array}$ & $\begin{array}{l}46 \\
100.0^{\mathrm{a}} \\
100.0 \\
1.00^{\mathrm{b}}\end{array}$ \\
\hline Carabelli trait 16,26 & $\begin{array}{l}\mathrm{n} \\
\% \text { symmetry } \\
\% \text { symmetry (absent-absent exc.) } \\
\text { rho }\end{array}$ & $\begin{array}{l}275 \\
83.6^{\mathrm{a}} \\
80.7 \\
0.81^{\mathrm{b}}\end{array}$ & $\begin{array}{l}170 \\
88.8^{\mathrm{a}} \\
84.8^{\mathrm{b}} \\
0.91^{\mathrm{b}}\end{array}$ & $\begin{array}{l}238 \\
81.1^{\mathrm{a}} \\
78.3 \\
0.73^{\mathrm{b}}\end{array}$ & $\begin{array}{l}46 \\
78.3^{\mathrm{a}} \\
76.7 \\
0.81^{\mathrm{b}}\end{array}$ \\
\hline Metaconule 16,26 & $\begin{array}{l}\mathrm{n} \\
\% \text { symmetry } \\
\% \text { symmetry (absent-absent exc.) } \\
\text { rho }\end{array}$ & $\begin{array}{l}223 \\
82.1^{\mathrm{a}} \\
71.2 \\
0.82^{\mathrm{b}}\end{array}$ & $\begin{array}{l}165 \\
79.4^{\mathrm{a}} \\
63.4 \\
0.73^{\mathrm{b}}\end{array}$ & $\begin{array}{l}204 \\
81.4^{\mathrm{a}} \\
73.8 \\
0.83^{\mathrm{b}}\end{array}$ & $\begin{array}{l}36 \\
69.4^{\mathrm{a}} \\
57.7 \\
0.62^{\mathrm{b}}\end{array}$ \\
\hline Hypocone reduction 17,27 & $\begin{array}{l}\mathrm{n} \\
\% \text { symmetry } \\
\% \text { symmetry (absent-absent exc.) } \\
\text { rho }\end{array}$ & $\begin{array}{l}231 \\
86.6^{\mathrm{a}} \\
- \\
0.88^{\mathrm{b}}\end{array}$ & $\begin{array}{l}127 \\
84.3^{\mathrm{a}} \\
- \\
0.82^{\mathrm{b}}\end{array}$ & $\begin{array}{c}192 \\
84.9^{\mathrm{a}} \\
- \\
0.83^{\mathrm{b}}\end{array}$ & $\begin{array}{l}54 \\
92.6^{\mathrm{a}} \\
- \\
0.80^{\mathrm{b}}\end{array}$ \\
\hline Distal accessory ridge 33,43 & $\begin{array}{l}\mathrm{n} \\
\% \text { symmetry } \\
\% \text { symmetry (absent-absent exc.) } \\
\text { rho }\end{array}$ & $\begin{array}{l}278 \\
85.3^{\mathrm{a}} \\
59.0 \\
0.68^{\mathrm{b}}\end{array}$ & $\begin{array}{l}165 \\
81.8^{\mathrm{a}} \\
48.3 \\
0.56^{\mathrm{b}}\end{array}$ & $\begin{array}{l}230 \\
90.4^{\mathrm{a}} \\
60.7 \\
0.71^{\mathrm{b}}\end{array}$ & $\begin{array}{l}53 \\
90.6^{\mathrm{a}} \\
68.8 \\
0.75^{\mathrm{b}}\end{array}$ \\
\hline Lingual cusp number 35,45 & $\begin{array}{l}\mathrm{n} \\
\% \text { symmetry } \\
\% \text { symmetry (absent-absent exc.) } \\
\text { rho }\end{array}$ & $\begin{array}{l}263 \\
84.0^{\mathrm{a}} \\
- \\
0.63^{\mathrm{b}}\end{array}$ & $\begin{array}{l}155 \\
85.8^{\mathrm{a}} \\
- \\
0.74^{\mathrm{b}}\end{array}$ & $\begin{array}{c}235 \\
84.3^{\mathrm{a}} \\
- \\
0.74^{\mathrm{b}}\end{array}$ & $\begin{array}{l}59 \\
86.4 \\
- \\
0.43^{b}\end{array}$ \\
\hline Protostylid 36,46 & $\begin{array}{l}\mathrm{n} \\
\% \text { symmetry } \\
\% \text { symmetry (absent-absent exc.) } \\
\text { rho }\end{array}$ & $\begin{array}{l}248 \\
87.5^{\mathrm{a}} \\
76.5 \\
0.80^{\mathrm{b}}\end{array}$ & $\begin{array}{l}146 \\
96.6^{\mathrm{a}} \\
94.5^{-} \\
0.95^{\mathrm{b}}\end{array}$ & $\begin{array}{l}227 \\
93.0^{\mathrm{a}} \\
77.8 \\
0.88^{\mathrm{b}}\end{array}$ & $\begin{array}{l}37 \\
91.9^{a} \\
66.7 \\
0.73^{b}\end{array}$ \\
\hline Deflecting wrinkle 36,46 & $\begin{array}{l}\mathrm{n} \\
\% \text { symmetry } \\
\% \text { symmetry (absent-absent exc.) } \\
\text { rho }\end{array}$ & $\begin{array}{l}159 \\
76.7^{\mathrm{a}} \\
51.9 \\
0.61^{\mathrm{b}}\end{array}$ & $\begin{array}{l}105 \\
79.0^{\mathrm{a}} \\
52.2^{2} \\
0.63^{\mathrm{b}}\end{array}$ & $\begin{array}{l}196 \\
87.2^{\mathrm{a}} \\
69.9 \\
0.78^{\mathrm{b}}\end{array}$ & $\begin{array}{l}19 \\
100.0^{\mathrm{a}} \\
100.0 \\
1.00^{\mathrm{b}}\end{array}$ \\
\hline Metaconulid 36,46 & $\begin{array}{l}\mathrm{n} \\
\% \text { symmetry } \\
\% \text { symmetry (absent-absent exc.) } \\
\text { rho }\end{array}$ & $\begin{array}{l}258 \\
95.7^{\mathrm{a}} \\
35.3 \\
0.50^{\mathrm{b}}\end{array}$ & $\begin{array}{l}167 \\
96.4^{\mathrm{a}} \\
53.8 \\
0.76^{\mathrm{b}}\end{array}$ & $\begin{array}{l}235 \\
94.0^{\mathrm{a}} \\
41.7 \\
0.76^{\mathrm{b}}\end{array}$ & $\begin{array}{l}43 \\
95.3^{\mathrm{a}} \\
60.0 \\
0.75^{\mathrm{b}}\end{array}$ \\
\hline Entoconulid 36.46 & $\begin{array}{l}\mathrm{n} \\
\% \text { symmetry } \\
\% \text { symmetry (absent-absent exc.) } \\
\text { rho }\end{array}$ & $\begin{array}{l}244 \\
94.3^{\mathrm{a}} \\
77.0 \\
0.85^{\mathrm{b}}\end{array}$ & $\begin{array}{l}161 \\
91.3^{\mathrm{a}} \\
67.4 \\
0.77^{\mathrm{b}}\end{array}$ & $\begin{array}{l}218 \\
95.0^{\mathrm{a}} \\
79.2 \\
0.87^{\mathrm{b}}\end{array}$ & $\begin{array}{l}31 \\
80.6^{\mathrm{a}} \\
40.0 \\
0.53^{\mathrm{b}}\end{array}$ \\
\hline
\end{tabular}


TABLE 3. Continued

\begin{tabular}{clcccc}
\hline Traits and Teeth & & Malays & Chinese & Indians & $\begin{array}{c}\text { Negritos } \\
\text { (Jahai) }\end{array}$ \\
\hline Cusp number 37,47 & n & 232 & 132 & 188 & 41 \\
& \% symmetry & $85.8^{\mathrm{a}}$ & $83.3^{\mathrm{a}}$ & $92.6^{\mathrm{a}}$ & $87.8^{\mathrm{a}}$ \\
& \% symmetry (absent-absent exc.) & - & - & - & - \\
& rho & $0.82^{\mathrm{b}}$ & $0.78^{\mathrm{b}}$ & $0.84^{\mathrm{b}}$ & $0.77^{\mathrm{b}}$ \\
& & & & & \\
Groove pattern 37,47 & $\mathrm{n}$ & 223 & 132 & 206 & 35 \\
& \% symmetry & $77.1^{\mathrm{a}}$ & $78.8^{\mathrm{a}}$ & $76.7^{\mathrm{a}}$ & 68.6 \\
& \% symmetry (absent-absent exc.) & - & - & - & - \\
& rho & $0.63^{\mathrm{b}}$ & $0.63^{\mathrm{b}}$ & $0.68^{\mathrm{b}}$ & 0.36 \\
\hline
\end{tabular}

${ }^{1}$ exc, excluded; the dashes (-) indicate that no analysis was performed because definition of "absent" is equivocal. aP $=0.0037$

$\mathrm{b} \mathrm{P}<0.05$

assessed using univariate non-parametric analyses. Bonferroni's adjustment was adopted for multiple univariate testing (13 independent variables) to control Type 1 error. The alpha level of 0.05 was divided by 13, yielding an adjusted alpha value of 0.0037 .

Calculation of the Mean Measure of Divergence (MMD) between groups took account of the issues raised by Harris and Sjøvold (2004) and (Irish, 2006). Differences in the frequencies of occurrence of each of the 13 dental traits between the four groups were analyzed using chi-square analysis at an alpha level of 0.05 to identify influential traits. According to Harris and Sjøvold (2004), these tests are important for selection of traits, as only those associated with significant outcomes should be used as input into the mean measure of divergence (MMD) computations to avoid negative values. These researchers also recommended that negative MMD coefficients be replaced with zero only when the coefficients are used for subsequent graphical representation.

The MMD analysis utilized dichotomous data. The frequencies of occurrence were transformed using Anscombe computations (Equation 2) to stabilize sampling variance. Harris and Sjøvold (2004) defined the computation of the MMD as follows: "the difference between samples $i$ and $j$ for the frequencies of trait $k$ is calculated and then this difference is squared and the correction term is subtracted. The sum of corrected squared differences was averaged according to the number of traits."
Mean measure of divergence (MMD) is

$$
\mathrm{MMD}=\frac{1}{\mathrm{r}} \sum_{\mathrm{k}=1}^{\mathrm{r}}\left(\theta_{\mathrm{ik}}-\theta_{\mathrm{jk}}\right)^{2}-\left(\frac{1}{\mathrm{n}_{\mathrm{ik}}+0.5}+\frac{1}{\mathrm{n}_{\mathrm{jk}}+0.5}\right)
$$

$r$, number of traits

$\mathrm{k}$, dental trait

$i, j$, samples from group $i, j$

$\mathrm{n}_{\mathrm{i} \mathrm{k}^{\prime}}$ scorable samples in i group for trait $\mathrm{k}$

$\mathrm{n}_{\mathrm{j} \mathrm{k}^{\prime}}$ scorable samples in $\mathrm{j}$ group for trait $\mathrm{k}$

Anscombe's transformation,

$$
\theta=\sin ^{-1}\left(1-2\left(\frac{m+\frac{3}{8}}{n+\frac{3}{4}}\right)\right)
$$

$\mathrm{m}$, frequency of trait presence

$n$, scorable specimens

The standard deviation of MMD is

$$
\mathrm{SD}=\sqrt{\frac{2}{\mathrm{r}^{2}} \sum_{\mathrm{k}=1}^{\mathrm{r}}\left(\frac{1}{\mathrm{n}_{\mathrm{ik}}}+\frac{1}{\mathrm{n}_{\mathrm{jk}}}\right)^{2}}
$$

The MMD coefficients are considered to be significant at an alpha level of 5\% when they are twice the corresponding standard deviations.

For ease of interpretation, MMD coefficients were used as input into a hierarchical cluster analysis to generate a classification tree dendrogram. Clustering methods used Ward's linkage and measurement between pairs of groups was based on squared Euclidean distance. The output was rescaled to numbers between 0 and 25 . 


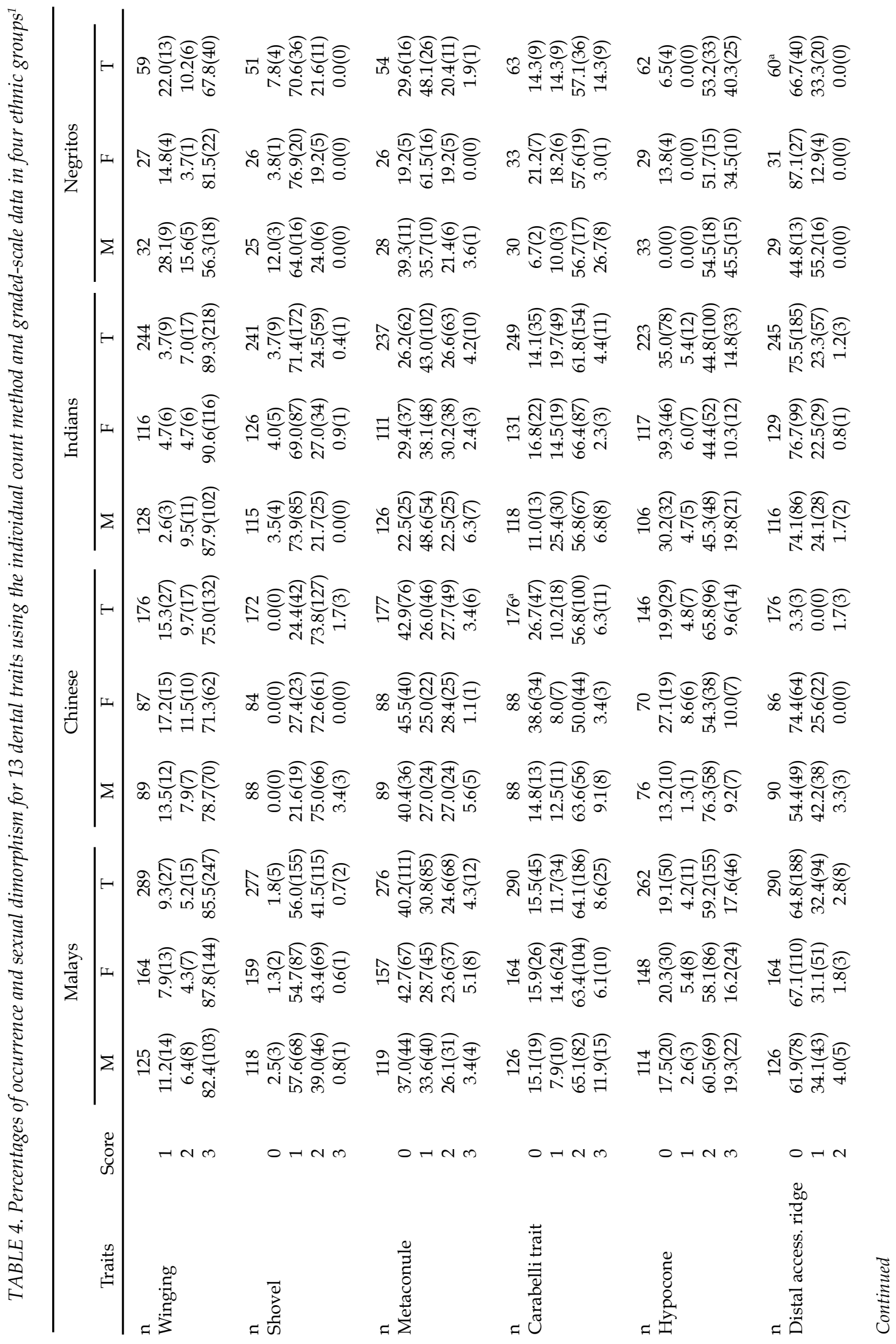




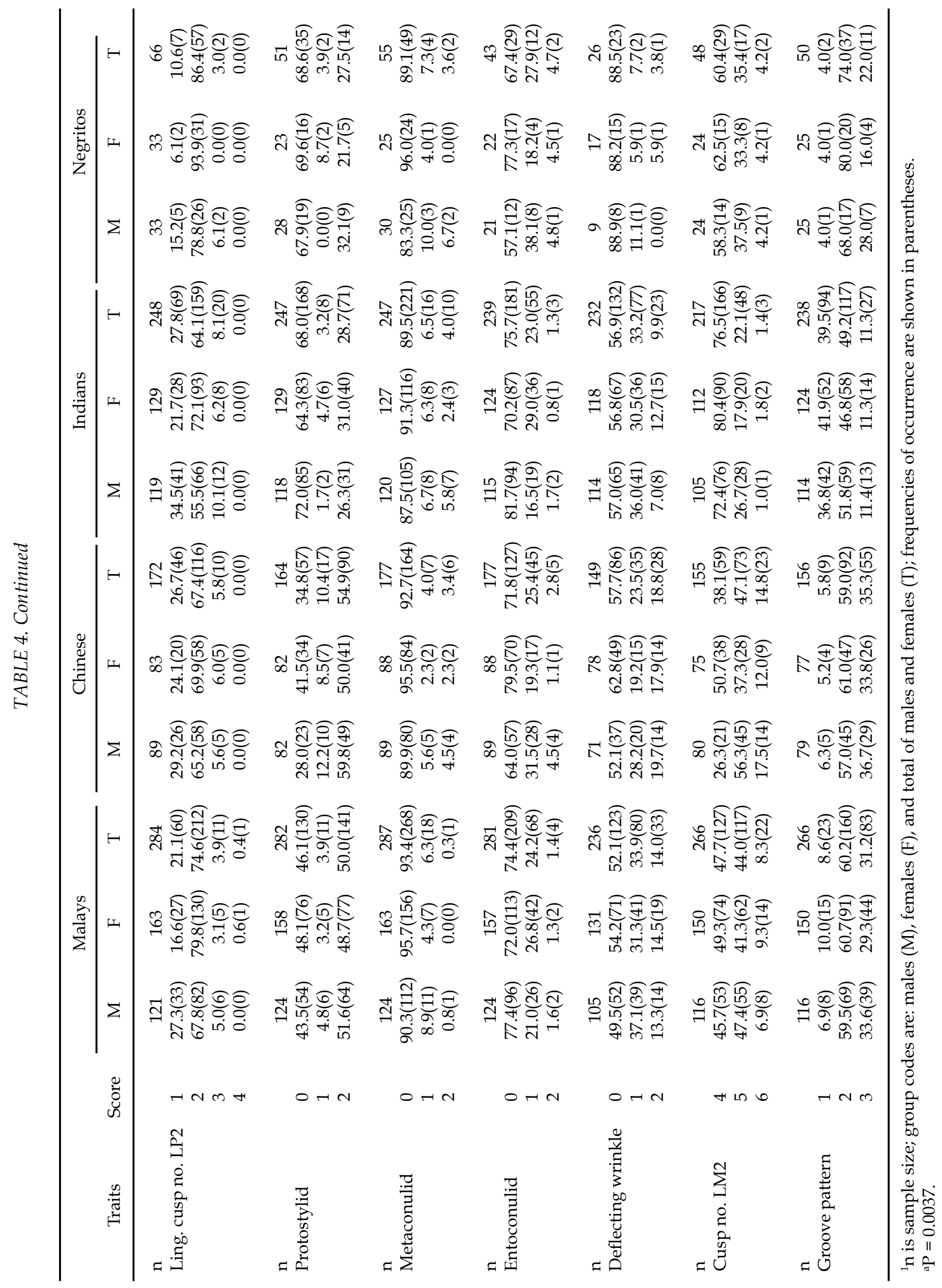




\section{RESULTS}

Most of the intra-observer errors using absencepresence data were less than $10 \%$ and only 15 of 100 intra-observer error observations were in the range of $11 \%$ to $18 \%$. The percentages of error recorded for fullgrade scoring were higher than for absence-presence data and the differences were only one grade apart.

The patterns of symmetry-asymmetry were similar in both sexes, except for hypocone reduction in Chinese and Jahai, and the metaconulid in Indians. After combining the data for both sexes, most traits were expressed symmetrically based on high to moderate values of correlation coefficients and concordance analyses (Table 3).

Table 4 shows frequencies of occurrence of dental traits in males and females for each of the four ethnic groups. Winging of upper central incisors, shoveling, metaconule, deflecting wrinkle, groove pattern, metaconulid, protostylid, hypocone, lingual cusp number of premolar, four-cusped lower second molar, and entoconulid showed no evidence of significant sexual dimorphism in any of the four ethnic groups. Sexual dimorphism was found to be significant at an alpha level of 5\% (Bonferroni's adjustment) for a couple of traits. Carabelli cusp (maximum expression of Carabelli trait) occurred more frequently in males than females in the Chinese sample, while pit and furrow forms were more frequent in female Chinese. The distal accessory ridge was significantly more frequent in Jahai males than females.

Figure 1 shows significant differences at the 5\% significance level in the frequencies of occurrence of 11 dental traits (sexes combined) between the four ethnic groups and compares the overall profiles of frequencies between the four ethnic groups. Ethnic group differences were not significant for two dental traits; entoconulid and metaconulid. Malays showed intermediate frequencies of occurrences for all dental traits while Chinese tended to show high frequencies for some traits and low frequencies for others. Shoveling, winging, protostylid, deflecting wrinkle, distal accessory ridge,

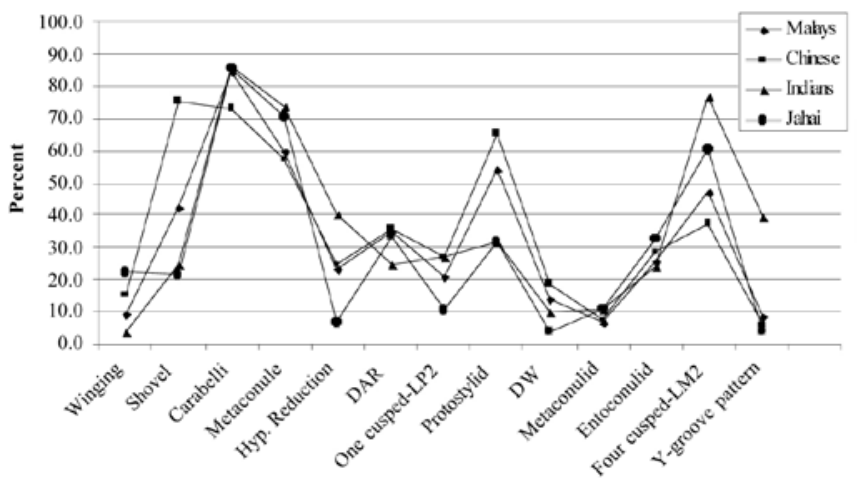

Fig. 1. Frequencies of occurrence of dental crown traits in four ethnic groups using dichotomous data. and one-lingual cusped premolar frequencies were high in Chinese, whereas Carabelli trait, metaconule and fourcusped molars were the least frequently observed traits. The Indian group was characterized by a high frequency of Carabelli trait, metaconule, reduced hypocone, fourcusped lower second molars and Y-groove patterns, and a low frequency of winging, shoveling, distal accessory ridge, protostylid and entoconulid. The Jahai exhibited low frequencies of occurrences of shoveling, hypocone reduction, one-cusped premolars, deflecting wrinkle, and Y-groove patterns. Only winging frequency was found to be high in the Jahai cohort. Differences of $10 \%$ or less in frequencies of occurrence were not associated with statistical significance, as shown by the entoconulid and metaconulid.

Nine dental traits discriminated Indians from Malays and Chinese. Five showed high frequencies in Malays and Chinese; namely, winging, shoveling, distal accessory ridge, protostylid, deflecting wrinkle, whereas four were associated with high frequencies in Indians: metaconule, hypocone reduction, four-cusped lower second molars, and Y-groove pattern. Four other dental traits were not discriminative; Carabelli trait, one-cusped premolars, entoconulid and metaconulid.

When comparing Malays and Chinese, winging, shoveling, one-cusped premolars, protostylid and deflecting wrinkle were present more frequently in Chinese, while Carabelli trait and four-cusped molars were more frequent in Malays. All other dental traits examined did not discriminate between Malays and Chinese.

Table 5 shows the MMD coefficients matrix including tests of significance. All MMD coefficients were statistically significant at $\mathrm{P}<0.05$. MMD coefficients derived from an average of 11 dental traits (the frequencies of entoconulid and metaconulid were not statistically significant in all four ethnic groups and were, therefore, excluded from the MMD analysis) were further subjected to hierarchical cluster analysis to produce a dendrogram. Figure 2 shows the affinities between the four ethnic groups. Indians were separated at a rescaled number of 25 from the other three groups; Malays, Jahai and Chinese. At a rescaled number of approximately 14, Chinese were separated from Malays and Jahai.

\section{DISCUSSION}

Despite considerable time spent on training, the intra-observer error rates for some traits in this study were larger than those reported in other studies (Turner and Scott, 1977; Turner, 1987; Turner, 1990). This reflects the subjectivity involved in scoring methods for dental morphology. The categorical nature of the available scoring systems does not allow grading of the quasicontinuous spectra of tooth morphologies that may fall between categories. Nichol and Turner (1986) indicated that if a discordance of more than two-grades occurred, 
TABLE 5. Mean measure of divergence coefficients matrix ${ }^{1}$

\begin{tabular}{lcccc}
\hline & Malays & Chinese & Indians & Jahai \\
\hline Malays & ---- & 0.068 & 0.144 & 0.075 \\
Chinese & 0.000 & --- & 0.320 & 0.227 \\
Indians & 0.000 & 0.000 & ---- & 0.186 \\
Jahai & 0.000 & 0.000 & 0.000 & --- \\
\hline
\end{tabular}

${ }^{1}$ Tests of significance in cells below diagonal; MMD coefficients in cells above diagonal.

and the presence-absence discordance was more than $10 \%$, then problems exist in the scoring method. Comparing intra-observer error for full-graded scoring and presence-absence scoring between this study and that of Nichol and Turner (1986) revealed similar results for entoconulid, groove pattern, cusp number of lower second molar and hypocone reduction. The results in the present study indicated better reliability for scoring several traits including shoveling, Carabelli trait, distal accessory ridge, deflecting wrinkle, protostylid and lingual cusp number of lower second premolar, whereas results for the metaconule and winging were slightly better in the study by Nichol and Turner (1986). Difficult traits to score consistently in the three major ethnic groups were the metaconule and distal accessory ridge using dichotomous categories. This study confirmed, as one would expect, that dichotomous data display better reliability, as quantified by concordance rates, than full-graded scoring methods. Consistent with those results, Palomino et al. (1977) indicated their preference for using dichotomous data rather than fullgraded scoring methods that increase the likelihood of misclassification.

Bilateralism was expressed similarly in males and females for all four ethnic groups. This result justified combining males and females for subsequent asymmetrysymmetry analysis. The frequencies of occurrence and degrees of expression of most traits showed significant symmetry, reflecting common developmental control for both sides of the dentition (Potter et al., 1976). Exceptions were lingual cusp number and groove pattern in Jahai, suggesting caution is needed in using dental traits observed on the distal tooth of a series because these teeth showed evidence of higher asymmetry (Garn et al., 1966a). However, these traits are useful to comparing

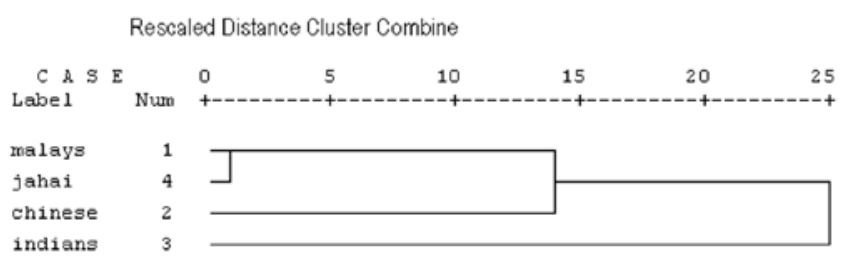

Fig. 2. Dendrogram of four ethnic groups with sexes pooled. trait simplification between groups.

Several of our findings were similar to those of previous studies in other populations. Percentages of symmetrical expression were generally higher than $75 \%$ for the majority of traits, similar to findings of Harris and Bailit (1980) and Noss et al. (1983b). When absence-absence pairs were excluded from the analysis, symmetry percentages were reduced (Mayhall and Saunders, 1986) especially for traits displaying low frequencies of occurrence (Townsend et al., 1990). Two traits in Jahai, lingual cusp number of lower second premolars and molar groove pattern, did not exhibit significant symmetry and were associated with moderate to low correlations in contrast to the results of Baume and Crawford (1979) who reported strong correlations but non-significant symmetry in Mexican and Belizean populations. Several traits showed high symmetry but the values of correlation coefficients were not consistently high. Percentages of concordance between sides, when absent-absent pairs were excluded, paralleled the values of correlation coefficients. Excluding absent-absent pairs is thought to reduce bias in the analysis of asymmetry (Townsend et al., 1990).

Assessment of asymmetry for each grade revealed large discordance for several traits, ranging from absence on one side to maximum expression on the antimeric tooth. This occurred infrequently and to varying degrees among the four ethnic groups. Two traits consistently showed large discordances in the four ethnic groups; deflecting wrinkle and protostylid. There were three traits, shoveling, Carabelli trait and distal accessory ridge, which were consistently free from large discordances in all four ethnic groups. In conclusion, the present findings support the premise of common genetic control on both sides of the dentition with environmental influences causing minor deviation from perfect symmetry. This suggests that replacement of missing values with antimeric values is biologically and statistically acceptable.

Significant sexual dimorphism (after Bonferroni's adjustment) was found only in Chinese and Jahai; Carabelli trait in Chinese and distal accessory ridge on the canine in the Jahai. The distal accessory ridge was found more often in Jahai males, which is consistent with Scott (1977) who studied the frequencies and degrees of expression of the distal accessory ridge in seven ethnic groups in the United States of America. Carabelli trait in Malaysian Chinese was more common in males, a similar result to that reported in Japanese and Chinese samples (Iwai-Liao et al., 1996), Southern Chinese (Hsu et al., 1999), Australian Aborigines (Townsend and Brown, 1981) and Indian Jats (Kaul and Prakash, 1981). In contrast, Hanihara (1977), Turner and Hanihara (1977), Scott (1980), Manabe et al. (1992) and Rusmah (1992) did not find any sexual dimorphism in the occurrence of this trait. In essence, the amount of sexual dimorphism for dental trait expression seems to vary between different 
populations.

Based on our preliminary analyses of within-group variations, the 13 dental traits scored in this study were considered to be suitable for population variation studies (Turner et al., 1991). This suitability was based on several criteria, such as an apparently strong genetic influence on the ontogeny of the traits (Tocheri, 2000), low sexual dimorphism and strong symmetry.

Inter-sample comparisons have been used in the past to define so-called "racial dental complexes" for Mongoloid, Caucasoid and Australoid groups. Hanihara's (1968) Mongoloid dental complex identifies four traits, UI1 and UI2 shoveling, deflecting wrinkle, protostylid and metaconule. In our samples the observed dental traits generally conformed to accepted models, except for the metaconule, for which the Indian sample displayed the highest frequency compared with Malays, Chinese and Jahai.

According to Turner's Mongoloid dichotomy (Turner, 1990), four crown traits distinguish Sinodonts from Sundadonts. Shoveling, double shoveling and deflecting wrinkle are common in Sinodonts, whereas 4cusped lower second molar are common in Sundadonts. In our results Jahai and Malays fitted the Sundadont description, while Chinese showed the Sinodont crown trait pattern.

Tratman (1950) described Indians as Indo-Europeans who frequently exhibit Carabelli trait, and the Malays and Chinese as Mongoloids who show high frequencies of shoveling, double shoveling, entoconulid and more complex occlusal surfaces. In our study, findings for Malays, Chinese and Jahai were consistent with some of Tratman's comments but those for Carabelli trait, entoconulid and double shoveling were not. Double shoveling was not scored in our study. The entoconulid did not provide statistically significant discrimination in the present study, although Indians exhibited the lowest relative frequency.

The frequencies of Carabelli trait found in this study were generally high when compared with other published material for Mongoloid populations (Rusmah, 1992; Iwai-Liao et al., 1996; Hsu et al., 1999). Only one article about Wainwright Eskimos by Hershey (1979) provides figures that approximate those obtained for Carabelli trait in this study. Hershey found a $92 \%$ frequency of occurrence for Carabelli trait while in this Mongoloid sample the frequency was around 75\%$85 \%$. An unexpected trend was found in the cuspal category (maximum expression for Carabelli trait). According to Tratman (1950), Indians should have a high frequency of Carabelli cusp but in this study they actually recorded the lowest frequency of $4.4 \%$ only. Several other researchers including Kraus (1959), Hershey (1979), Mayhall et al. (1982), and Mayhall (1999) have opined that only the Carabelli cusp (maximum category) provides discrimination between Caucasoid and Mongoloid groups. In fact, they suggested that the pit and intermediate categories occurred more frequently in Mongoloid populations. In this Malaysian sample, total frequencies of occurrence of Carabelli trait only discriminated Chinese from the other three groups but they failed to show any discriminating power for Malays, Jahai and Indians. This result raises doubt about the utility of Carabelli trait as a Caucasoid marker.

The Indian sample generally displayed less complex occlusal and palatal surfaces, consistent with Tratman's (1950) anatomical descriptions of his sample, and partially compatible with the Caucasoid dental complex (Mayhall et al., 1982). From six dental traits proposed by Mayhall et al. (1982), only two traits, low prevalence of shovel and high prevalence of hypocone reductions, fit the Indian dental characteristics found in this study.

The Jahai, who represent Negritos from the Malaysian Peninsula, have a similar pattern of dental characteristics as the Aetas from the Philippines (Hanihara, 1992). The similarities noted include low frequencies of shoveling, deflecting wrinkle, and high frequencies of 4-cusped lower second molars.

Phenetic distances based on dental variations seem to support historical reports. The first documented reports suggest that for a period of time Malays lived side by side with Orang Asli until the "Perang Sangkel" war broke out between them, causing the Orang Asli to move deep into the jungle (Pusat Perkembangan Kurikulum, 1998). Another documented report is that the Malays could have originated from mixture of protoMalays (Orang Asli) with other ethnic groups, such as Thailanders, Arabs or Chinese (Nagata, 1979; Dentan et al., 2001). Unfortunately, our results do not enable us to decide which historical version better explains the close affinity between Malays and Orang Asli. Both documented reports generate postulations of potential genetic admixture and sharing of ancestors that could explain the phenetic closeness between the two groups.

\section{CONCLUSIONS}

Most of the dental traits studied showed symmetrical expression in their frequencies of occurrences and low sexual dimorphism. The analyses performed indicated that there are two main groups of Malaysians. The Mongoloid group comprises Malays, Negritos (Jahai) and Chinese, whereas the Indian sample can be classified as Indo-European. The Mongoloid group can be further subdivided, with the Jahai and Malays fitting the Sundadont profile and the Chinese conforming to a Sinodont profile, as described by Turner (1990). Phenetic distances based on dental variation lend support to the historical perspectives of Malaysian population relationships. 


\section{LITERATURE CITED}

Bang G, Hasund A. 1971. Morphologic characteristics of the Alaskan Eskimo dentition: I. Shovel-shape of incisors. Am J Phys Anthropol 35:43-48.

Bang G, Hasund A. 1972. Morphologic characteristics of the Alaskan Eskimo dentition: II. Carabelli cusp. Am J Phys Anthropol 37:35-40.

Baume RM, Crawford MH. 1979. Discrete dental trait asymmetry in Mexico \& Belize. J Dent Res 58:1811.

Dahlberg AA. 1956. Materials for establishment of standards for classification of tooth characters, attributes, and techniques in morphological studies of the dentition. Zollar Laboratory of Dental Anthropology: University of Chicago.

Dentan RK, Endicott K, Gomes AG, Hooker MB. 2001. Malaysia and the "Original People." Boston: Allyn and Bacon, p 12-16.

Dupont WD, Plummer WD. 1997. PS power and sample size program available for free on the internet. Controlled Clin Trials 18:274.

Escobar V, Conneally PM, Lopez C. 1977. The dentition of the Quekchi Indians: anthropological aspects. Am J Phys Anthropol 47:443-452.

Garn SM, Dahlberg AA, Lewis AB, Kerewsky RS. 1966a. Groove pattern, cusp number, and tooth size. J Dent Res 45:970.

Garn SM, Kerewsky RS, Lewis AB. 1966b. Extent of sex influence on Carabelli`s polymorphism. J Dent Res 45:1823.

Haeussler AM, Irish JD, Morris DH, Turner II CG. 1989. Morphological and metrical comparison of San and Central Sotho dentitions from Southern Africa. Am J Phys Anthropol 78:115-122.

Hanihara K. 1968. Mongoloid dental complex in the permanent dentition. Proceedings of the VIIIth International Congress of Anthropological and Ethnological Sciences, vol. 1. Tokyo: Science Council of Japan, p 298-300..

Hanihara K. 1977. Dentition of the Ainu and the Australian aborigines. In: Dahlberg AA, Graber TM, editors. Orofacial growth and development. Hague: Mouton, p 195-200.

Hanihara T. 1992. Negritos, Australian Aborigines, and the "Proto-Sundadont" dental pattern: the basic populations in East Asia, V. Am J Phys Anthropol 88:183-196.

Harris EF, Bailit HL. 1980. The metaconule: a morphologic and familial analysis of a molar cusp in humans. Am J Phys Anthropol 53:349-358.

Harris EF, Sjøvold T. 2004. Calculation of Smith's mean measure of divergence for intergroup comparisons using nonmetric data. Dental Anthropology 17:8393.

Hassanali J. 1982. Incidence of Carabelli's trait in Kenyan Africans and Asians. Am J Phys Anthropol 59:317-
319.

Hershey SE. 1979. Morphology of the Wainwright Eskimo dentition: Carabelli's structures. Ossa 6:115124.

Howitt D, Cramer D. 2003. An introduction to statistics in psychology, 2nd ed. Harlow: Pearson Education Limited.

Hsu JW, Tsai PL, Hsiao TH, Chang HP, Lin LM, Liu KM, Yu HS, Ferguson D. 1997. The effect of shovel trait on Carabelli's trait in Taiwan Chinese and Aboriginal populations. J Forensic Sci 42:802-806.

Hsu JW, Tsai PL, Hsiao TH, Chang HP, Lin LM, Liu KM, Yu HS, Ferguson D. 1999. Ethnic dental analysis of shovel and Carabelli's traits in a Chinese population. Aust Dent J 44:40-45.

Irish JD. 2006. Who were the ancient Egyptians? Dental affinities among Neolithic through postdynastic peoples. Am J Phys Anthropol 129:529-543.

Iwai-Liao Y, Guo L, Higashi Y, Sun D, Tsubai T, Kim J-G, Takeuchi M. 1996. A preliminary study on inherited tooth morphology characters of Japanese and Chinese young adults - with special reference to the Carabelli tubercle. Okajimas Folia Anat Jpn 73:1-6.

Kannappan JG, Swaminathan S. 2001. A study on a dental morphologic variation - the tubercle of Carabelli. In: Brook A, editor. Dental morphology 2001. Sheffield: Sheffield Academic Press, p 43-47.

Kaul V, Prakash S. 1981. Morphological features of Jat dentition. Am J Phys Anthropol 54:123-127.

Kieser JA. 1984. An analysis of the Carabelli trait in the mixed deciduous and permanent human dentition. Arch Oral Biol 29:403-406.

Kraus BS. 1959. Occurrence of the Carabelli trait in southwest ethnic groups. Am J Phys Anthropol 17:117-123.

Manabe Y, Rokutanda A, Kitagawa Y. 1992. Nonmetric tooth crown traits in the Ami Tribe, Taiwan Aborigines: comparisons with other East Asian populations. Hum Biol 64:717-726.

Mayhall JT, Saunders S, Belier PL. 1982. The dental morphology of North American whites: a reappraisal. In: Kurten B, editor. Teeth: form, function, and evolution. New York: Columbia University Press, p 245-258.

Mayhall JT, Saunders SR. 1986. Dimensional and discrete dental trait asymmetry relationship. Am J Phys Anthropol 69:403-411.

Mayhall JT. 1999. The dental complex: a morphological smokescreen or compass? In: Townsend GC, Kieser JA, editors. Perspective in human biology. Nedlands: Centre for Human Biology, p 1-7.

Meredith HV, Hixon EH. 1954. Frequency, size, and bilateralism of Carabelli`s tubercle. J Dent Res 33:435440.

Moskona D, Vainder M, Hershkovitz I, Kobyliansky E. 1996. Bilateral asymmetry in dental discrete traits in human isolates: south Sinai Bedouin tribes. 
Anthropol Anz 54:289-306.

Nagata J. 1979. Malaysian mosaic: perspectives from a poly-ethnic society. Vancouver: University of British Columbia Press.

Nichol CR, Turner II CG. 1986. Intra and interobserver concordance in classifying dental morphology. Am J Phys Anthropol 69:299-315.

Noss JF, Scott GR, Potter RH, Dahlberg AA, Dahlberg T. 1983a. The influence of crown size dimorphism on sex differences in the Carabelli trait and the canine distal accessory ridge in man. Arch Oral Biol 28:527530.

Noss JF, Scott GR, Potter RHY, Dahlberg AA. 1983b. Fluctuating asymmetry in molar dimensions and discrete morphological traits in Pima Indian. Am J Phys Anthropol 61:437-445.

Palomino H, Chakraborty R, Rothhammer F. 1977. Dental morphology and population diversity. Hum Biol 49:61-70.

Potter RH, Nance WE, Yu P-l, Davis WB. 1976. A twin study of dental dimension. II. independent genetic determinants. Am J Phys Anthropol 44:397-412.

Pusat Perkembangan Kurikulum. 1998. Budaya, Pantang Larang dan Amalan Kesihatan Orang Asli Semenanjung Malaysia: Kementerian Pendidikan Malaysia and United Nations Children's Fund (UNICEF).

Rothhammer F, Lasserre E, Blanco R, Covarrubias E, Dixon M. 1968. Microevolution in human Chilean populations. IV. shovel shape, mesial-palatal version and other dental traits in Pewenche Indians. Z Morphol Anthropol 60:162-169.

Rusmah M. 1992. The cusp of Carabelli in Malaysians. Odontostomatol Trop 15:13-15.

Scott GR. 1977. Classification, sex dimorphism, association, and population variation of the canine distal accessory ridge. Hum Biol 49:453-469.

Scott GR. 1980. Population variation of Carabelli's trait. Hum Biol 52:63-78.

Scott GR, Turner II CG. 1997. The anthropology of modern human teeth. Cambridge: Cambridge University Press.

Thomas CJ, Kotze TJ, Nash JM. 1986. The Carabelli trait in the mixed deciduous and permanent dentitions of five South African populations. Arch Oral Biol 31:145-147.

Tocheri MW. 2000. The effects of sexual dimorphism, asymmetry, and inter-trait association on the distribution of thirteen deciduous dental non-metric traits in a sample of Pima Amerindians. Dental Anthropology 14:1-8.

Townsend GC, Brown T. 1981. The Carabelli trait in Australian Aboriginal dentition. Arch Oral Biol 26:809-814.

Townsend GC, Yamada H, Smith P. 1986. The metaconule in Australian Aboriginals: an accessory tubercle on maxillary molar teeth. Hum Biol 58:851-862.

Townsend GC, Yamada H, Smith P. 1990. Expression of the entoconulid (sixth cusp) on mandibular molar teeth of an Australian Aboriginal population. Am J Phys Anthropol 82:267-274.

Tratman EK. 1950. A comparison of the teeth of people. Indo-European racial stock with the Mongoloid racial stock. Dent Rec 70:31-53.

Turner II CG, Hanihara K. 1977. Additional features of Ainu dentition. V. peopling of the Pacific. Am J Phys Anthropol 46:13-24.

Turner II CG, Scott GR. 1977. Dentition of Easter islanders. In: Dahlberg AA, Graber TM, editors. Orofacial growth and development. Hague: Mouton, p 229-249.

Turner II CG. 1987. Late Pleistoceine and Holocene population history of East Asia based on dental variation. Am J Phys Anthropol 73:305-321.

Turner II CG. 1990. Major features of Sundadonty and Sinodonty, including suggestions about East Asian microevolution, population history, and Late Pleistocene relationships with Australian Aboriginals. Am J Phys Anthropol 82:295-317.

Turner II CG, Nichol CR, Scott GR. 1991. Scoring procedure for key morphological traits of the permanent dentition: the Arizona State University Dental Anthropology System. In: Kelley MA, Larson LS, editors. Advances in dental anthropology. New York: Wiley-Liss, p 13-31.

Zainuddin R. 2003. Sejarah Malaysia, 2nd ed. Kuala Lumpur: Fajar Bakti. 